\title{
What's possible? A look into the future of grassland farming in New Zealand
}

\author{
B.D. CAMPBELL \\ AgResearch, Grasslands Research Centre, PB 11008, Palmerston North \\ bruce.campbell@agresearch.co.nz
}

\begin{abstract}
This paper considers several of the forces that will shape the future of grassland farming in New Zealand over the next 15 years, including: global changes in food consumer needs, international competition in commodity food production, national regulations for sustainable resource management, global biotechnology advances, biosecurity threats and global climate change. Our current state of preparedness for change is considered, including an assessment of how education, research, grasslandbased industry infrastructure and New Zealand businesses should be preparing for these future changes. The role of innovation to create biotechnology and high-value products (such as functional foods and therapeutic proteins) is given particular attention. It is suggested that region-specific clusters of education, research and business are required to develop these future opportunities.

Keywords: competitive forces, grassland farming, research and development
\end{abstract}

\section{Introduction}

I expect to spend the rest of my life in the future, so I want to be reasonably sure of what kind of future it's going to be. That is my reason for planning.

Charles Kettering

New Zealand grassland farming has been highly successful in the past by adapting to change but the pace of change is quickening. Most businesses plan strategy on a five-year time horizon or less, yet strategic positioning should have a horizon of a decade or more, not a single planning cycle. Looking further out and anticipating change will be useful for New Zealand to capture opportunities from change in a world where change is happening faster.

In this paper I attempt to create a longer horizon by looking out for future changes which might impact on our industry in the next 15 years and beyond. Inevitably this will be wrong. However the intent in attempting to predict a future on this time scale is to stimulate thinking and discussion about what the world for grassland farming in New Zealand could look like, and how we in the New Zealand grassland industry can shape a strategy for a successful future.

\section{A tool for developing strategy}

To analyse these trends I will use the Porter's Five Forces model (Porter 1980). This model identified five forces (Figure 1) that shape every industry and every market. These forces determine the intensity of competition and hence the profitability and attractiveness of an industry. A further step is to examine external market influences, such as changing consumer tastes, state of the economy, level of government legislation and the global market. Although this microeconomic model is not intended for application to a whole industry and has recognisable flaws for today's dynamic market, it is useful as a simple starting tool to collate information on future trends to guide long-term strategy development for our grassland industry.

\section{Some emerging driving forces for the future industry}

A number of specific issues are likely to emerge for grassland farming over the next 15 years (Table 1). These should not be analysed in isolation but rather as a package of changes, which in combination will

Figure 1 Porter's Five Forces model (adapted from Porter 1980).

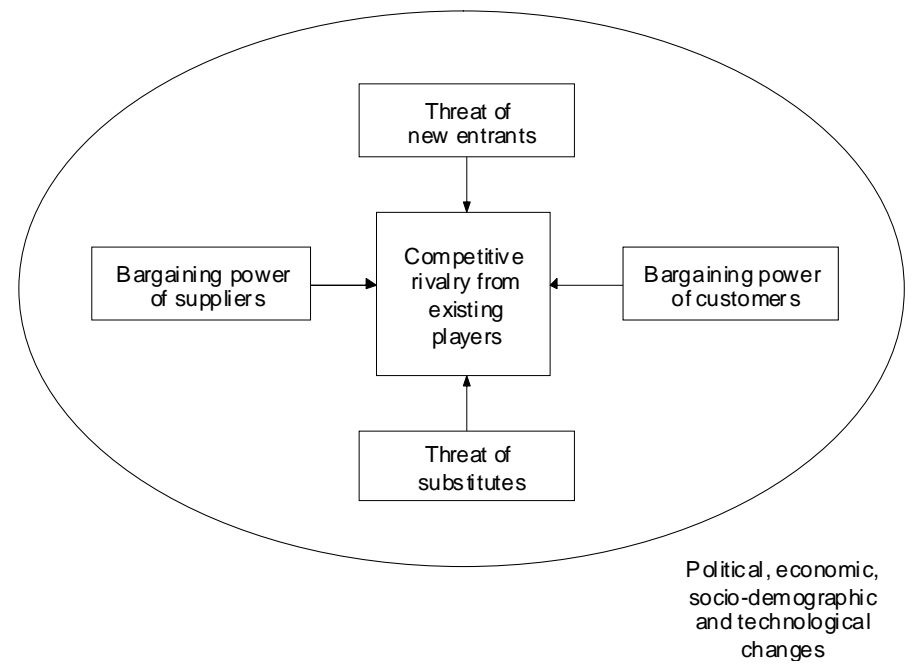


have results that cannot be predicted if each is analysed in isolation.

Bargaining power of customers Some 7.2 billion people will populate the world in 2015 , up from 6.1 billion in 2000 (National Intelligence Council 2002). The challenge before global agriculture between now and 2050 is to feed at least 3 billion more people on less land, while reducing the number of non-sustainable inputs (de Greef 1999). Increased life expectancy and falling birth rates will contribute towards a shift to an aging population in high-income developed countries. Youth bulges will persist in developing countries with most growth in urban centres. By 2015 more than half the world population will be urban. Developed countries will enjoy improved wealth and health status with non-infectious diseases posing a greater health risk than infectious diseases, although growing microbial resistance to antibiotics and accelerating international movements of people will facilitate the spread of infectious diseases (National Intelligence Council 2002).

The customers for our New Zealand grassland industry products will be supplying consumers with changing expectations. The consumer of the $21^{\text {st }}$ century will be better informed and will have a higher awareness of food products and their influence on health and well being (de Rooij 2000). They will demand individual solutions and this will shift the food market from supply towards a consumer demand mode. A thorough understanding of consumer preferences will be an important prerequisite for success in the future. Major consumer trends are influenced by changing demographics, such as an aging population, more women at work, smaller families, less food preparation time, convenience, more eating out of home, more awareness of food, and eating as a social event. Recent food and drink scares have made people even more quality and safety conscious, and environmental considerations play an increasing part in the buying decision of the consumer.
There is a trend towards functional foods, lower fat foods and less red meat consumption. In the developing functional foods market, major functionality claims are for gut health (especially in Japan and Europe), heart health (especially USA and Europe), promoting natural defences, and boosting energy levels. The future outlook for health-based and health-driven foods is strong. An overall growth rate of $10 \%$ per annum for the next 5 years is possible, significantly outperforming the overall food and beverage market growth of about $2 \%$ per annum (Weststrate et al. 2002).

Real income in developing countries is also projected to increase, and in these countries the increase in disposable income is projected to be spent at least half on food, mainly upgrading diets to include more costly foods such as meat (Gardner 2000). This also creates new markets and opportunities for New Zealand meat- and milk-based products.

\section{Bargaining power of suppliers}

The raw materials and energy for New Zealand grassland farming are primarily supplied directly from 
the climate and natural environment, in the form of solar radiation, water, carbon, nitrogen, etc to grow grass. Labour is another significant supply factor for the industry along with further energy for equipment and processing.

Significant land use changes have already occurred in New Zealand between 1994 and 2002, with 1.5 million ha less in grazing crops and fallow, and a $20 \%$ decline in the sheep population to 39.5 million. Dairying increased to $23 \%$ of exports. The dairy herd totalled 5.2 million, up 1.3 million on 1994 , with the biggest growth in Canterbury, Otago and Southland. Only 12 million ha of land remains in grazing, and about 200000 ha of marginal land was reverted to bushland (Statistics New Zealand 2003).

In the next 15 years the increasingly urban based population in New Zealand is likely to expect greater legislation and management of rural landscapes. Expectations are growing for greater protection of the environment by the grassland farming industries. This has implications in terms of protection of the environment and implementation of the Resource Management Act and other legislation. Some key issues include: land use impacts on water quality, new management systems for intensive land use, managing greenhouse gas emissions, coexistence of different land use enterprises to encourage multiple enterprises, and greater participatory decision making involving industries, user groups, communities and iwi to adapt to future challenges. A section of New Zealand society and business is also exerting political pressure for legislation to restrict and regulate the adoption of new technologies such as biotechnology by land-based industries.

Climate change is an underlying trend that will exert an increasing influence on New Zealand seasonal climate and climate extremes over the next decades (Ministry for the Environment 2001a). Grassland farming has substantial opportunities for productivity gains and diversification under climate change, but also faces some serious long-term risks. In New Zealand the climate is expected to warm by only about two-thirds of the global mean temperature in the coming decades due to the moderating influence of the ocean, with from +0.6 to $+2.8{ }^{\circ} \mathrm{C}$ change in temperature and $-20 \%$ to $+30 \%$ change in rainfall in the next 100 years depending on region (Ministry for the Environment 2001a). The greatest impact on grassland agriculture will be through a change in climate variability and extremes, with eastern regions experiencing more frequent and severe droughts, and western regions (and some eastern areas) more prone to flooding and greater variability of rainfall. These general trends are considered relatively robust but the precise magnitude depends on future emission levels (Ministry for the Environment 2001a).

With these predicted future changes in climate, pasture production will generally increase $10-20 \%$ by 2030 through higher carbon dioxide levels and an extended growing season (Ministry for the Environment 2001b). There will be a reduction in feed quality in pastures as far south as Waikato, with an increased incidence of subtropical species such as kikuyu. Feed quality and predictability of feed supply will also decrease further in dry, eastern areas. Climate variability already has a significant impact on the New Zealand economy, for example the farm gate cost to agriculture of the 1997/98 El Niño drought was estimated at over $\$ 425$ million. Climate variability is expected to increase. As an example of likely implications, the vulnerability of the dairy industry to drought could increase with planned expansion into Canterbury. There will be a greater frequency of irrigation bans in future because of a combination of increased water demand for expanding farm productivity along with the predicted changes in rainfall patterns. Higher temperatures will increase the incidence of exotic pests and diseases but the effects are yet to be quantified.

New Zealand trade and tourism volumes are predicted to significantly increase over the next 15 years. With this comes the threat of new pests and diseases which may impact on supply. In the coming decade there is also an increasing threat of global bioterrorism risks adding a further dimension to considerations on biosecurity. Outbreaks of dangerous organisms would be an issue both in terms of supply but also in terms of the bargaining power of customers and potential for bans on food exports from New Zealand. Consequently, biosecurity is becoming a major issue. At present MAF intercepts 86000 at risk goods at the border each year which have been found to carry more than 4600 unwanted organisms (Goldson et al. 2002). Recent events with pest incursions (e.g. Goldson et al. 2002; Heath 2002) impacting on both plants and livestock question the adequacy of existing border controls to prevent pest incursions. Climate change may exacerbate these effects as outlined above. The already serious biosecurity situation is likely to worsen through rapidly growing tourism and trade and this is being compounded by an increase in the diversity of nontraditional trading partners.

\section{Threat of new entrants}

Livestock production is increasing most rapidly in the same regions where consumption is rapidly increasing (e.g. Asia and especially China). Thus meat 
and milk production is expanding four to five times more rapidly in developing countries than in the developed countries (Rae 2002). By 2020 developing countries will produce $60 \%$ of the world's meat and $52 \%$ of the world's milk. China will lead meat production and India milk production (Delgado et al. 1999).

In the next 15 years South American products are expected to enter the commodity meat and dairy export markets as they are declared disease-free (e.g. foot-and-mouth) and this is expected to substantially intensify competition in the low cost, efficient end of market. Exports of agricultural production technologies from New Zealand will further increase this competition. Maintaining and enhancing a highvalue, safe New Zealand brand image will be important to restrict the impact of new entrants from South America and Asia on our share of the international food market.

\section{Threat of substitutes}

Amongst the livestock types, annual market growth rates for pork and poultry of $6-8 \%$ in developing countries are about double those of meat and milk (Delgado et al. 1999). In developed countries, meat and dairy products have recently been associated with less healthy eating habits. Strategies to manage branding, image and respond to these issues are identified above with respect to the bargaining power of consumers.

\section{Competitive rivalry from existing players}

The agricultural biotechnology industry is expected to expand globally but specific predictions are inherently difficult (de Greef 1999) because of the speed of current technological advances. Part of the focus currently is on input traits with the aim of increasing yields with reduced external inputs. Herbicide and insect resistant crops are already being grown. Future advances will focus on abiotic stresses such as drought, heat and salt tolerance. By contrast, an emerging group of new technologies target output traits such as modifications of the carbohydrate, protein, oil and fibre content of plants, and the development of functional foods (e.g. enriched with vitamins), non-allergenic foods. Depending on the manufacturing costs, plants may also become more frequent bioreactors for the production of high-value proteins for pharmaceutical and other applications. There will be further improvements in factors influencing the nutritional value of forages and feed supplements. The current rapid advances in genomics are expected to soon allow the development of entirely new biosynthetic pathways in plants (de Greef 1999). Some of these technologies will be adopted by existing international players for intensive grassland production and this will increase the competitive rivalry.

The debate on the virtues and perils of biotechnology in the production of transgenic crops started in 1983 and has intensified and become more controversial in recent years (Vasil 2003). The world wide area of transgenic crops has grown from 2 million hectares in 1996 to nearly 80 million hectares in 2003 (Vasil 2003). This trend is likely to continue with increased planting of transgenic crops in China, India and other countries. In the United States, $80 \%$ of soybeans, $70 \%$ of cotton and $38 \%$ of maize planted in 2003 were transgenic. The total market for transgenic seed now exceeds NZ\$6 billion. Over the coming two decades new varieties of plants will continue to be developed by traditional breeding and

Table 2 Generations of transgenic crops predicted to be in commercial production (adapted from Vasil 2003).

\begin{tabular}{|c|c|c|}
\hline First generation: up to 2005 & Second generation: $2005-2015$ & Third generation: 2015 and beyond \\
\hline $\begin{array}{l}\text { - Resistant to herbicides } \\
\text { - Resistance to insects } \\
\text { - Resistance to viruses }\end{array}$ & $\begin{array}{l}\text { - Resistant to herbicides, } \\
\text { pests and pathogens } \\
\text { - Tolerant to drought, salt, } \\
\text { metals, high and low } \\
\text { temperatures } \\
\text { - Improved nutritional } \\
\text { quality (proteins, oils, } \\
\text { vitamins, minerals) } \\
\text { - Improved flavours } \\
\text { - Elimination of antigens } \\
\text { - Production of vaccines, } \\
\text { therapeutic proteins, } \\
\text { pharmaceuticals } \\
\text { - Phytoremediation }\end{array}$ & $\begin{array}{l}\text { - Altered plant architecture } \\
\text { - Manipulation of flowering } \\
\text { - Manipulation of fruit and } \\
\text { seed quality, size and } \\
\text { number } \\
\text { - Improved photosynthetic } \\
\text { efficiency } \\
\text { - Improved nutrient } \\
\text { assimilation } \\
\text { - Manipulation of heterosis } \\
\text { and apomixis }\end{array}$ \\
\hline
\end{tabular}


selection. Howe ver, biotechnology is expected to improve these varieties further by introduction of characteristics (Table 2) that cannot be manipulated or transferred with traditional methods (Vasil 2003).

As we move towards 2015 some biotechnologies will continue to face moral and religious controversy. There will be more complex governance procedures before release including consultation for a broader participation in the management of emerging technologies, and assessments to provide balanced evidence on environmental or health impacts of biotechnologies (Juma 2000). It is expected that there will be a gradual relaxation of rules and regulations around the development, testing and field release of transgenic organisms. The USA will take the lead, with Europe and New Zealand following except in those instances where there is a likelihood of risk to human health and the environment. Transgenic crops, forages and livestock will become an integral part of future international agriculture.

Political, economic, socio-demographic and technological changes

The global economy is well positioned to achieve a sustained period of dynamic growth through 2015 (National Intelligence Council 2002). Economic liberalisation and globalisation could see cycles in financial markets with overshoot and turbulence in economies. In 2015 advances in agricultural technologies will mean food production can meet demand but problems of distribution and availability will remain. Water and energy supplies will come under increasing pressure. In the developing world $80 \%$ of water usage goes into agriculture. This figure is not sustainable and in 2015 a number of countries will be unable to maintain their levels of irrigated agriculture. The global economy will continue to become more energy efficient but sustained economic growth will increase energy demand by $50 \%$. North America, Australia and New Zealand, the traditional magnets for migrants, will continue to have the highest rates of population growth among the developed countries, between 0.7 and $1.0 \%$.

Further reduction in barriers to trade around the world will result in an expanding market for agricultural products (Gardner 2000). Modelling by Rae (2002) suggests that a comprehensive liberalisation of agricultural trade is likely to make a significant contribution to arresting the decline in the role of grasslands in international trade. This would have benefits for New Zealand grassland farming. New Zealand is well placed to take advantage of more liberalised trade over the next 15 years due to previous removal of domestic subsidies, high efficiency and low import restrictions.

Science and technology is a key uncertainty in prediction for 2015 for which the future is tough to call with any precision. In 2000 the volume of information was estimated to double every 5 years, in 2003 it will double in 18 months and in 2005 it will double every 72 days. New technologies will create completely new opportunities for grassland farming, especially in agricultural biotechnology.

Socio-economic and cultural considerations are becoming more important. Although dismissed or marginalised in previous technical conversations, it is now clear that technological innovation without an appraisal of its societal impact is likely to be much reduced in effectiveness.

Contemporary environmental problems will persist and grow over the next 15 years. With increasingly intensive land use, land degradation and greenhouse gas emissions will increase. Environmental issues will become more mainstream, particularly in the developed world. The consensus on the need to deal with these issues will increase but progress will be patchy. Developed countries will manage these local environmental issues. Over the next 15 years pressures on the environment as a result of economic growth will ease due to less energy-intensive economic development and technological advances.

The Government has set out policies for meeting New Zealand's targets under the Kyoto Protocol, including an emissions charge applied to fossil fuels and industrial process emissions which will approximate the international emissions price, but be capped at $\$ N Z 25$ a tonne of carbon dioxide equivalent. It will apply in the Kyoto Protocol's first commitment period $(2008-2012)$ and not before 2007. The agricultural sector will be exempt from any price measure (emissions charge or trading regime) in the first commitment period, provided the sector invests in research to identify options for reducing agricultural emissions. The Government is currently consulting with industry on controversial options to levy sheep, dairy, beef and deer farmers to fund research into reducing greenhouse gas emissions from agriculture. In the future these policies are expected to add to costs of grassland production but new technologies such as reduction in ruminant methane will also provide benefits in greater efficiency, higher productivity per animal and lowered nitrogen losses to the environment.

\section{Strategic positioning to influence the future}

A competitive strategy is about performing different activities from rivals or similar activities in different ways, in order to deliver a unique mix of value. The 
aim is to create more value than competitors can. New possibilities open up because of change. The Porter model can assist the search for strategies to reduce the power of competitive forces for the benefit of the New Zealand grassland industry (Table 3). Key issues revolve around the bargaining power of customers, the bargaining power of suppliers, and the threat of new entrants.

Innovation, biotechnology and Intellectual Property

Investment in continuous innovation combined with the pursuit of higher-margin products and expanded market opportunities will be important to create unique new products, processes and technologies for the industry. These technological advances are a critical component of New Zealand's current system and will be increasingly important in future. Progress must be accelerated to reduce the threat of new entrants and to differentiate products against rivalry from existing players.

A key strategy to restrict the entry of new entrants to the market will be protection of unique IP only available to the New Zealand industry, through patenting and other instruments to protect proprietary know-how. This requires research and development (R\&D), legal capabilities and investment.

More complex governance procedures should be designed and implemented before the release of new biotechnologies. This includes advance consultation for a broader stakeholder participation in the management of emerging technologies.

Advances in generation of new knowledge must be coupled with improved education and learning to result in rapid technology adoption rates in the industry. Current levels of private sector and public sector investment in R\&D for grassland agriculture are increasing with further government investment (Minister of Research, Science and Technology 2003) and the inception of co-funding of R\&D by industry and government through research consortia. In 2003/ $04, \$ 238.95$ million is being spent by government on Economic Goal investment, of which a proportion benefits grassland agriculture. However, the current total R\&D investment by New Zealand remains below equivalence with many of our competitors (Woodfield
2002) and must increase through greater industry investment to meet these future challenges. Regionally based clusters of education, research and business are required to develop these future opportunities.

\section{Higher-margin products}

A thorough understanding is needed of consumer preferences and principles behind them to address increasing sophistication and demand mode in food consumers. This requires linking of consumer science, marketing and communication to the consumer. The industry should pursue higher-margin products such as functional foods aimed at disease risk reduction and daily health benefits for healthy people. In the next 5 years the global sectors to grow include heart health and weight management, physical and mental performance and "good for you" products such as probiotics and antioxidants (Weststrate et al. 2002). Key factors will be taste, convenience and trust. In the next 10-15 years fitting nutrition to human genetic profiles and genetically profiled diseases (nutrigenomics) will emerge.

In that time frame biotechnology is expected to see a comeback in Europe for delivering ingredients for functional foods. This will occur first in developed countries but functional foods are also likely to become important in developing countries e.g. vitamins, minerals and heart health. Opportunities also exist from producing novel plants or animals expressing high-value therapeutic proteins such as 
vaccines.

A greater focus on high-value products will provide unique market positioning and a greater return to allow an increased $R \& D$ investment. It will also allow matching of New Zealand expectations for improved standards of living while reducing pressure on the natural environment, by focussing intensified production on a smaller land area.

\section{A differentiated product portfolio}

A diversity in domestic production activities will encourage growth and innovation with complementary activities of small and large businesses and clustering of activities where appropriate. Complementing the higher-margin, researchintensive product segments of the industry, there will be a continuing opportunity for large-scale, highlyefficient food ingredient supply as in the current dairy industry. This segment will be driven by cost reduction, efficiency increases and large scale of production and product supply to maintain market position. A more liberalised trade will encourage growth in this sector in the short- to medium-term.

A strategy must also identify what not to do and some hard calls must be made. There will be increasing pressure to move away from low-margin commodity products with a low knowledge input. Constant improvement of operational effectiveness is not usually sufficient to maintain competitive position as there is rapid diffusion of best practice to competitors and this will apply to remaining commodity producers in New Zealand. Greater automation and a higher skilled labour force are likely.

There must be trade-offs where activities are incompatible. Currently the view is expressed that organic and transgenic production activities are not compatible but there is growing evidence that coexistence is possible. Further research could assist in identifying how diverse production systems can be managed side-by-side in the same landscape.

\section{Brand and marketing}

A shared vision for a distinct New Zealand brand value is required. This could embody the images of innovative, safe, fresh, healthy and improved lifestyle. Associating this brand with rapidly tightening standards for food exports to the USA (to ensure food security and guard against bioterrorism) could allow a preferred supplier status for New Zealand.

\section{Stretched supply chain management}

Linking management of the supply of resources to match customer needs at various points in the value chain will be important in maintaining brand value and market position. This will allow matching of stakeholder and customer environmental expectations (with respect in particular to water, waste management and greenhouse gases, management of climate variability) to sustain production of a unique diversity of high-value products in the New Zealand landscape.

New Zealand business and investors should also develop a greater ownership stake in distribution and retailing channels for these products to reach closer to the final food consumer. This will have the dual benefit of increasing the margin to producers from value-added products and retaining customers in an increasingly competitive market.

\section{Integration and communication}

An integrated strategy is needed for the industry with greater connection between science, industry, education and government sectors. For example, a more effective border control and biosecurity system is required with greater communication between science, industry, MAF Biosecurity and other government agencies. To develop this integrated industry strategy, it would be important to encourage greater science representation on New Zealand company boards.

Rapid development and uptake of innovation in New Zealand grassland farming will require the development of regional innovation centres to accelerate discovery, R\&D and education. For example, the cluster of biologically-based CRIs, Fonterra, Massey University and the newly formed Manawatu BioCommerce Centre in Palmerston North allows great opportunity for a focus on plant biotechnology and breeding new forage plants, animal health and nutrition. This has the potential for world-class research and education to benefit New Zealand grassland farming.

\section{Conclusion}

Significant change is coming over the next 15 years, some of which is predictable and some of which is not. The New Zealand grassland industry should prepare for this change with an integrated, long-term strategy to guide future investment. In all the strategic opportunities identified, a strong R\&D activity is critical. Progress will be enhanced by the development of regional centres which couple research, education and business to focus research activity and increase industry and government investment in R\&D.

\section{REFERENCES}

Delgado, C.; Rosegrant, M.; Steinfield, H.; Ehui, S.; Courbois, X.C. 1999. Livestock to 2020: the next 
food revolution. International Food Policy Research Institute, 2020 Vision for Food, Agriculture and the Environment. Discussion Paper 28. 72 pp.

Gardner, B.L. 2000. International trade and the future of American agriculture. Journal of Agribusiness 18: 27-40.

de Greef, W 1999. A long-term perspective on Agbiotech. British Crop Protection Council Symposium Proceedings 72: 33-37.

Goldson, S.L.; Barlow, N.D.; Gerard, P.J.; Jackson, T.A.; Phillips, C.B.; Watson, R.; Rahman, A. 2002. Biosecurity for New Zealand's forage production systems. Proceedings of the New Zealand Grassland Association 64:135-138.

Heath, A.C.G. 2002. Recently introduced exotic animals and their parasites: what risk to New Zealand's biosecurity? Surveillance 29: 15-17.

Juma, C. 2000. Biotechnology in the global economy. International Journal of Biotechnology 2: $1-6$.

Ministry for the Environment 2001a. Climate Change Impacts on New Zealand. Ministry for the Environment, Wellington.

Ministry for the Environment 2001b. Climate Change: Likely Impacts on New Zealand Agriculture. Ministry for the Environment, Wellington.

Minister of Research Science and Technology 2003. Accelerating New Zealand's transformation: extracting value from knowledge. May 2003.
Ministry of Research Science and Technology, Wellington.

National Intelligence Council 2002. Global trends in 2015: a dialogue about the future with nongovernment experts. Renewable Resources Journal 20: 6-12.

Porter, M.E. 1980. Competitive strategy: techniques for analysing industries and competitors. Free Press, New York.

Rae, A.N. 2002. The role of grasslands in world food trade: projection of future trade policy reforms. New Zealand Journal of Agricultural Research 45: 3547.

de Rooij, J. 2000. The consumer of the $21^{\text {st }}$ century. pp.171-175. In: Towards an Agenda for Agricultural Research in Europe. Eds. Boekestein, A.; Diederen, P.; Jongen, W.M.F.; Rabbinge, R.; Rutten, H Wageningen Academic Publishers, The Netherlands.

Statistics New Zealand 2003. 2002 Agricultural Production Census http://www.stats.govt.nz/

Weststrate, J.A.; Poppel, G van; Verschuren, P.M. 2002. Functional foods, trends and future. British Journal of Nutrition 88: Suppl. 2 S233-S235.

Woodfield, D.R. 2002. The importance of agricultural research to New Zealand's future. Proceedings of the New Zealand Grassland Association 64: 1-5.

Vasil, I.K. 2003. The science and politics of plant biotechnology - a personal perspective. Nature Biotechnology 21: 849-851. 